\title{
Propositions for utilising emotional intelligence in construction organisations.
}

\author{
LAWANI, A. and MOORE, D.R.
}

2021

This is an Accepted Manuscript version of the following article, accepted for publication in International Journal of Construction Management. LAWANI, A. and MOORE, D.R. 2021. Propositions for utilising emotional intelligence in construction organisations. International journal of construction management, 21(2), pages 153-166. Available from: $h$ ttps://doi.org/10.1080/15623599.2018.1512028. It is deposited under the terms of the Creative Commons Attribution-NonCommercial License (http://creativecommons.org/licenses/by-nc/4.0/), which permits non-commercial re-use, distribution, and reproduction in any medium, provided the original work is properly cited. 
Dr Ama Lawani PhD, MSc, AHEA ${ }^{\text {a* }}$

and

Dr David R Moore PhD, BSc (Hons), DipLT, MCIOB ${ }^{\mathrm{b}}$

${ }^{a}$ Department of People, Organisation and Practice, Robert Gordon University, Aberdeen Business School. Aberdeen, UK;

${ }^{b}$ The Scott Sutherland School of Architecture \& Built Environment, Robert Gordon University, Aberdeen, UK.

Provide full correspondence details here including e-mail for the *corresponding author

Dr Ama Lawani

Lecturer

Department of People, Organisation and Practice

Robert Gordon University

Aberdeen Business School

Garthdee Road

Aberdeen AB10 7QE

E-mail:a.lawanil@rgu.ac.uk 


\section{Propositions for utilising Emotional Intelligence in Construction Organisations}

The Emotional Intelligence (EI) concept is prevalent within management literature and is recognised as an important skill for managers in achieving organisational effectiveness. However, scholars report an unwillingness by the construction industry to fully embrace this concept. This study aims to provide an assessment of Emotional Intelligence research that relates specifically to construction project managers (CPM) and construction professionals $(\mathrm{CP})$ through a literature review which involved a chronological and interpretive approach. Findings revealed that, in general, only a minimal number of investigations have been carried out with regards to the construction industry. Characteristics of reviewed studies include a predominance of quantitative methodologies and lack of consideration for both cultural orientation and the nature of the task/activity. It is suggested that studies of EI in construction need to consider concepts applied in social and management studies such as 'Identity and Culture' so as to discover more insights on how EI can be trained and utilized. The study offers relevant information for researchers, instructors and construction professionals on ways to harness practical benefits of EI.

Keywords: emotions, emotional intelligence, construction industry, construction project managers and professionals

\section{Introduction}

Construction projects are uniquely characterised by their complexity, diversity and nonstandardized nature of production (Sears et al. 2010) and the management of such projects involves the creation of a collaborative team consisting of the client, designer, contractor, supplier and project manager, all working together for relatively short periods of time (Mo, Dainty and Price 2006). The diversity of individuals working in a construction project gives rise to issues such as disparity in traits and behaviours, differing objectives, and conflicting interests. Consequently, such challenges place 
significant demands on the ability of construction professionals $(\mathrm{CP})$ and construction project managers $(\mathrm{CPM})$ to manage different stakeholders so as to achieve effective organization and execution of the project. As a result, the issues of poor leadership skills that relate to project relationships emerged (Pryke and Smyth 2006) and consequently the need to investigate psychological and sociological project components arose. As a response, Emotional Intelligence (EI) became recommended as a means of enhancing project performance in construction (Love et al. 2011; Pryke and Smyth 2006). The EI concept, which entered mainstream scholarly literature around the late $90 \mathrm{~s}$, is a ubiquitous term particularly in management and organisational literature. Research on EI spans across various fields and only relatively recently did construction project management begin to consider its use (Love et al. 2011; Van Rooy and Viswesvaran 2004).

However, for the construction industry in general, the issue of EI is more contentious due to the claimed characteristics of the industry, such as: being perceived as having a male dominated culture; based on transactional relationships; comprising a transient workforce (Lindebaum and Cassell 2012; Loosemore 2008), adoption of aggressive/authoritative management styles (Gritli and Oraz 2004), and fierce competition (Dainty et al. 2002). These perceptions of the construction industry are believed to emanate from early scientific management systems which were independent, impersonal and instruments of rationalisation with no place for emotions (Hancock and Tyler 2009). It has been argued that based on these views, CP and CPM resist the EI concept, because it is seen as denoting 'emotional weakness', in an industry that is predominantly male (Domagalski 1999; Loosemore and Galea 2008). This is arguably why knowledge on EI is limited in the construction industry (Mischung et al. 2015). 
Emotional Intelligence within the workplace (outside of construction) has been thoroughly researched, and the significance of EI and its relevance for successful organisational interrelationships is now being recognised as part of developments that are reconfiguring the workplace (Zhang and Fan 2013; Ashforth and Humphrey 1995; Kupers and Weibler 2008). However, when it comes to the unique nature of the construction industry, the application and usefulness of EI is unclear. For instance, although empathy and happiness are argued to be skills that contribute to managerial performance (Lyusin 2006; Goleman 2004), negative emotions such as antagonism and pride, rather than cheerfulness and empathy, are seen as a source of influence for men and ultimately effective for managing work relationships in a male - dominated industry (Overbeck et al. 2010; Sinaceur \& Tiedens 2006).

Furthermore, even though construction project management literature emphasises the need to explore leadership skills in the construction industry (Ozorhon et al. 2013; Toor and Ofori 2008), scholars have stressed the consistent unwillingness of construction professionals to embrace the Emotional Intelligence concept (Mischung, J.J. et al. 2015), along with an under-exploration of the concept in the construction industry (Pryke et al. 2015; Zhang and Fan 2013). Highlighting this point is the overview of EI in construction project management by Lawani (2016), which identified a total of only 24 articles. This seems somewhat paradoxical considering the numerous studies of EI prevailing in general organisational and management studies. The hesitancy of accepting EI and its under-exploration in construction hampers the development of EI research in the construction industry and subsequently achievement of the practical benefits of EI among construction project managers and professionals, which are 
dependent on recognising when to use it and knowing how to apply the skill effectively (Mischung et al. 2015). This study, therefore;

(1) Presents an account of existing EI literature within the context of the construction industry.

(2) Discusses potential lines of enquiry that can support future research on EI in construction.

(3) Deliberates the methodological concerns of exploring EI in such a context and

(4) Considers how an understanding of EI relevant to construction professionals can be obtained in order to promote EI in the construction industry.

The purpose of this study is to determine the underlying possible cause of the above issues cited by various scholars in relation to the resistance, perception and under-exploration of EI in the construction industry. The information provided herein is appropriate for construction projects because of the unique environment in which construction projects are performed. The multi-organisation and multistakeholder nature of construction projects give rise to numerous objectives and conflicting interest often leading to division in cultural and social aspects.

\section{Emotional Intelligence (EI)}

The appeal of EI mirrors the notion that an organisation's success is not solely determined by intellectual abilities such as analytical and problem-solving capabilities but also by abilities relating to emotions (Cote and Miners 2006). Though the origin of EI can be traced back to Thorndike's (1920) early concept of 'social intelligence' which is described as the ability to understand, manage others and get along with people, 
evidence of the EI construct is additionally found in the work of Gardner (1984) in his concept of multiple intelligences, where he identified intrapersonal and interpersonal intelligences.

The name Emotional Intelligence was first conceptualized by Salovey and Mayer (1990) and their model considered Emotional Intelligence as a mental ability representing an intelligence system. Its popularity increased further with the development of the Bar-on Emotional-Social Intelligence model and the Goleman Emotional Competency model (Zhang and Fan 2013; Fernandez and Extrema 2006). The latter is based on various competencies created and modified to predict efficiency and personal outcomes in a managerial setting (Bar-On 2006), while the former identifies major factors of social and emotional functioning that promote human psychological wellbeing and has an effect on intelligent behaviour (Bar-On 2006; Fernandez and Extrema 2006). EI has a plethora of definitions and a somewhat low level of agreement regarding the nature of the construct with different theoretical viewpoints existing. However, research reveals a consensus on the conceptualization that Emotional Intelligent is an ability or competency (Mcenrue and Groves 2006) and the various definitions of EI do not contradict, rather they complement each other (Law et al. 2004). Despite the debates and controversies surrounding the EI concept (Antonakis 2003, 2004; Landy 2005 and Locke 2005) it is argued that the different theoretical approaches to the concept should not be understood as a conceptual weakness but rather as an indication of robustness and theoretical maturity (Fernandez and Extrema 2006). 
The development of the concept can be appreciated in research studies which investigate differing issues such as: the challenges of managing emotional synergy among members of multicultural groups (Von Glinow et al. 2004), the effect of emotion on buying and selling decisions (Lerner et al. 2004), how emotions shape behaviour (Baumeister 2007) and the impact of regulating emotions on the quality of social interaction (Lopes et al. 2005). Similarly, current practical and theoretical studies on EI have extended the concept's boundaries to include areas specifically relevant to management practitioners, such as: the relationship between EI, work performance outcomes and leadership effectiveness (Rosete and Ciarrochi 2005), the link between EI and job performance (O'boyle et al. 2011; Sy et al. 2006), its effect on life satisfaction (Law et al. 2008), the relationship between EI and transformational leadership style (Mandell and Pherwani 2003; Barbuto and Burbach 2006) and its impact on management performance (Langhorn 2004).

\section{EI in the Construction Industry}

The construction industry has not been left out in the quest for improved performance. Love et al. (2011) state that finding ways to improve project performance has become a persistent problem faced by construction experts, educators and researchers. Emphasis has been on the development of operations management which focuses on optimization of production (Holweg 2007; Sprague 2007) through quantitative methodologies and an over reliance on instrumental/technical rationality (Hodgsen and Cicmil 2006). However, recent advances in the field of construction project management have resulted in a "switch of lenses" in order to examine the psychological (individual) and sociological (project participants) elements (Love et al. 2011; Love et al. 2002). 
Research into these issues have identified that a relational approach underpinned by effective leadership is significant in improving the management of construction projects (Smyth 2010; Winter et al. 2006).

EI has been suggested to be the 'sin qua non' of leadership (Walter et al. 2011), has been generally accepted as essential for effective interpersonal relationships (Pryke et al. 2015; Caruso and Salovey 2004), and is relevant in building productive project relationships (Druskat and Druskat 2006). Thus, the concept has been brought to view in construction project management textbooks and analysed in a small number of research articles published in construction journals. However, the construction industry has not been completely receptive to EI despite the trend to more collaborative working environments which has been acknowledged as pivotal to successful project delivery (Songer et al. 2004). Literature highlights a lack of consensus on the acceptability and applicability of EI in the construction industry. Authors, such as Loosemore et al. (2003) suggest that resistance to the construct is due to the cultural perception of EI within a highly technical environment, such that the word 'emotion' is alleged to indicate 'emotional weakness' in a male dominated industry (Domagalski 1999; Loosemore and Galea 2008). In addition, Simpson (2006) states that males evidence an apprehensive response to the word 'emotion'. In view of the fact that the role of leadership and particularly an individual's leadership style are major factors influential to the outcome of construction projects (Larsson et al. 2015), it is necessary to consider how EI skill can be advanced within construction project management.

There is a dearth of general understanding about EI in the construction industry (Pryke et al. 2015; Zhang and Fan 2013) and the constant debates on the relevance and the application of EI for construction professionals/ project managers (Mischung et al. 2015; Lindebaum and Cassell 2012), signify that the area still requires further 
development in relation to the context of construction. Although the predominance of a positivist approach into investigating the concept has been identified as one of the possible drawbacks of its development (Lawani 2016), more minutiae in relation to the utilization and practical benefits of EI is still required. Therefore, the aim of this paper, is to present an account of past studies that explored EI in the construction industry, discuss methodological issues and propose ways to improve the understanding of EI that will be relevant to its adoption by construction professionals.

\section{Method}

An overview of previous literature on emotional intelligence in a construction environment was conducted through a comprehensive search of studies on EI. An overview is typically a summary account or explanation of literature that attempts to reassess existing studies and describe its characteristics. It is used for various types of assessments and appraisals with varying degree of 'systematicity' (Grant and Booth 2009). Since the population of interest for this study is in the construction industry, the article selection was restricted to only studies conducted in a construction environment. A combination of keywords used in the search included: 'emotional intelligence' or 'emotion' appearing in the title or abstract. Where it was suitable, terms used in filtering included 'construction project management', 'construction industry' and/or 'construction management'. Since EI has roots in leadership theory, keywords such as 'leadership styles' were also used in combination with the initial keywords. Extra time was used in reading through the references of the final articles that were identified from the selection process. 
The search was methodically carried out across three main construction databases: ARCOM (Association of Researchers in Construction Management), ICONDA (International Construction Database) and ASCE (American Society of Civil Engineers). The ARCOM database comprises about 19 construction management journals, such as Construction Economics and Building, International Journal of Construction Education and Research and Journal of Construction Engineering and Management. It also contains peer reviewed conference proceedings. The ICONDA online repository contains peer reviewed CIB publications, SB proceedings and serial journal articles covering building and construction research. ASCE database contains peer-reviewed journals and conference proceedings.

Since the concept of leadership underpins EI, other keywords such as 'leadership styles' were used in combination with the keyword 'emotional intelligence' in the literature search, consequently, the search extended to journals such as Leadership Quarterly journal and Human Relations journal. These journals were retrieved in order to obtain the required breadth of studies of EI in the construction industry. It was observed that most of the retrieved articles were also documented in Google Scholar, as it is often claimed that this provides a quick and easy way to broadly search for scholarly articles. Information was extracted and analysed deductively. Because the wide-ranging focus of management studies hinders aggregation and quantifiable analysis of results (Tranfield et al. 2003), synthesis was achieved by drawing similarity and differences from the characteristics of the gathered studies through interpretative means. [Table 1 shows the process by which articles were retrieved].

\section{INSERT TABLE 1 here}


The above procedure is congruent with Lawani's (2016) article selection process. According to Lawani, 20 papers were retrieved from this process with a further 4 papers identified from referenced papers in the articles, bringing the total to 24 . However, a fresh search identified two additional articles which were not previously identified, apparently due to the very recent date (2016) in publication of these articles. Therefore, a total of 26 articles were identified and used in the current study. Countries represented in the review and the number of articles identified from each are: UK (1 review paper and 5 quantitative studies); US (3 quantitative and 2 qualitative studies, and 1 review paper); China (3 quantitative studies); Thailand (2 quantitative studies); Australia (2 quantitative studies); Serbia (1 quantitative study); South Africa (1 quantitative study); New Zealand (1 review paper), 4 general review/discussion papers (no specific country). [Table 2 provides the characteristics of reviewed studies].

According to Grant and Booth (2009), a review that seeks to survey and appraise existing literature, aims for a comprehensive search, conducts a quality assessment and is typically narrative, can be classed as a systematic review. This study highlights what is known about EI in a construction industry context, how research is often conducted in this context and recommends an approach for future research in order to make the concept of EI more relevant for construction project managers and professionals (due to the nature of their environment).

The relative low number of identified papers for this study corresponds with the total number of studies (49 papers) that have generally investigated leadership in the construction industry (Toor and Ofori 2008) and Clarke's (2010) identification of only 5 studies that specifically examined EI in a project context. 


\section{INSERT TABLE 2 here}

\section{A Review of EI in the construction industry}

The prevalence of EI in the academic literature gives an impression that much research has occurred in the construction industry in relation to the concept, when in reality there exist a low number of articles exploring the emotional intelligence of construction professionals. This may be due to the interpretations of masculine stereotypes within the industry (Loosemore and Galea 2008) or the aggressive behaviour and communication mannerism of individuals which engender ineffective research in construction industry (McLennan and Scott 2002; Loosemore 1998). The total number of articles (26) confirms assertions about a limited number of studies of EI in the construction industry (Saini and Soni 2016) and, in general, leadership in the construction industry (Toor and Ofori 2008).

Out of the 26 papers that were identified, 7 were reviews and/or discussions on EI in construction. Cao and $\mathrm{Fu}$ (2011) reviewed the benefits of EI in construction project performance and suggested that the role of EI in construction was the provision of a leadership skill that aids effective communication with team members to enhance project performance. Cacamis and El Asmar (2013) and Love et al. (2011) supported Cao and Fu's claims about the benefits of EI in construction. While the former suggested that developing EI can improve project stakeholders' relationships, the latter emphasised training of construction professionals with respect to EI, so as to enable them to moderate the effects of stress and identify ways of improving their team's 
effectiveness. Livesey (2013) discussed the relevance of EI in construction and the benefits of using qualitative approaches in developing EI. The review carried out by Mischung et al. (2015) provided a more detailed explanation of EI in relation to prevalent models of EI, relevance and criticisms of EI and considerations on how EI should be applied in construction management curriculums. A relatively current review on EI in the construction industry simply re-emphasised the importance of EI in construction project management, highlighting the need for interpersonal skills in construction (Saini and Soni 2016). It was observed that in each review, a comment on the low number of EI research projects in the construction industry was clearly stated. However, there is no appropriate explanation, appraisal or assessment of previous EI literature in these reviews in relation to ways of advancing its adoption. There is no explicit direction on the way forward to harnessing the real benefits of EI in the construction industry. The current paper presents an assessment of the characteristics of previous EI studies, methodological concerns and propositions on how to achieve the practical benefits of EI in construction.

Based on the current review, it was observed that a majority of the studies investigated EI from a quantitative approach as analysis was mainly to determine the impact of emotional intelligence on specific personality or organisational variables. Most of these studies showed that EI correlated positively with the inquired variable. Only three articles were identified as having used a qualitative approach in their study, reflecting a preference for positivism in construction research (Phua 2013). Furthermore, while a proportion of the studies examined the effect of EI in performing certain tasks or during specific stages within the construction project life cycle, others interpreted their results 
from a standpoint of the cultural dimension of the country of investigation (Sunindijo and Hadikusumo 2013).

Research by Love et al. (2011) and Zhang and Fan (2013) tends to support the relevance of EI as they explored the influence of EI in construction and examined the benefits of a project manager's EI to project performance respectively. Cao et al. (2011) illustrated a positive correlation between EI and transformational leadership behaviour of project managers in a construction project context. They also seem to address the argument concerning the validity of studies that rely on same source data (Lindebaum and Cartwright 2010), although a critical evaluation of the article provided insufficient information on the sample used by the authors. While some researchers such as Cao and $\mathrm{Fu}$ (2011) and Mo et al. (2006) opine that EI may be relevant to construction professionals, as it impacts on transformational leadership, others such as Lindebaum and Jordan (2012), and Lindebaum and Cassell (2012) argue that the effect of EI on a construction project manager's performance has been exaggerated and that an industry such as construction may not benefit from the use of EI as a management tool. It was suggested that a 'differentiated lens' should be applied when examining the function of EI in a specific organizational context such as construction environment (Lindebaum and Cassell 2012). Taking a closer look at the dimensions of EI, Sunindijo and Zou (2013) found that self and relationship management are necessary in performing safety management tasks, while transformational leadership does not influence the performance of such tasks. This view is analogous to that of Tixier et al. (2014) who discovered that project participants with a positive and neutral emotional state may be more likely to take more risks than those with a negative emotional state. However, a study by Lindebaum and Fielden (2010) offered insights into how negative emotions 
could be applied to assist project participants in ensuring the progress of construction projects. Furthermore, whereas Sunindijo et al. (2007) claimed project management could benefit from EI because it has an impact on the behaviour of project managers, Butler and Chinowsky (2006) investigated the need for a greater perception of emotional intelligence within the construction industry and found that some components of EI relate to transformational leadership, even though the transactional leadership style is usually more preferred in the context of construction (Mischung et al. 2015; Gritli and Oraz 2004). In addition, authors such as Mo, Dainty and Price (2006) emphasise the relevance of EI and suggest that the concept of an individual's EI along with the means of providing training on EI to construction students be explored. Consistent with these suggestions, a weak relationship between educational programmes and the EI of construction students in the UK was established (Mo et al. 2007), which may be due to the nature of the programmes taught and/or other unidentified factors.

It is observed that the contentions of EI in construction border around its relevance in terms of its benefits to the construction project manager/professionals and how to promote the concept through students' training, suggesting a gap in existing literature. Mischung et al. (2015) asserts that only educating and evaluating individuals in EI may not be successful because of the lack of effectively teaching one how to implement the skill and knowing when it is suitable to apply it. In a qualitative study conducted by Satchwell and Smallwood (2016), 25\% of the research participants admitted to having no idea about what EI was, while $75 \%$ claimed to know about EI. However, about half of the EI knowledgeable group could not clearly and correctly explain EI when 
investigated further. The characteristics of these studies raise some concerns which are addressed in the next section.

\section{Discussions}

The fact that individual and psychological elements are given little attention in the construction literature (Phua 2013) is revealed from the number of studies identified for the review process. The low number of research studies on emotional intelligence in the construction industry not only raises concern in the area of its development but more importantly it raises the need to explore how existing studies were carried out and what was found in order to identify potential areas for further work.

Firstly, the reliance of using a quantitative approach to investigate emotional intelligence is arguably insufficient when evaluating the concept in relation to an individual's behaviour. The predominant use of quantitative methodologies emanates from the psychological domain in which emotional intelligence lies and this approach stems from the positivist course often adopted by natural scientists through the use of statistical measures to give evidence based reports. In so doing, qualitative psychological concepts are converted into quantitative facts to demonstrate confidence in the way results are represented (Fineman 2004), thus, a justification of the use of traditional self-report measurement scales in the majority of the studies reviewed. However, using quantitative methods to examine a socially constructed concept devalues its development, because it focuses on an individual's view towards a behaviour/performance and not the actual behaviour due to social desirability bias (Ofori and Toor 2009). This therefore implies that a majority of the reviewed studies only investigated the views of individuals concerning EI and not what is practiced in 
reality or what behaviour is used in their environment in relation to EI. Moreover, some authors claim that an authoritative leadership style is majorly used in the construction industry of certain countries, for instance in Turkey (Giritli and Oraz 2004).

Secondly, based on the concept of culture dimensions (Hosfstede 1983), the view that the effectiveness of a leadership style is considerably different across cultures has been recognised (Muller and Turner 2010). Therefore, the impact of EI to some degree should reflect parallel views within similar cultures and vice versa. However, studies conducted in countries of similar cultures reported differing effects of EI. For instance, Sunindijo and Hadikusumo's (2013) study of Thailand's construction industry revealed that, due to the collectivist nature of their culture, professionals with high EI frequently used accommodating conflict resolution styles. Whereas, in China, Der foo et al. (2004) investigated how the level of EI of an individual influenced a negotiation process and identified a significantly lower score for the more emotionally intelligent person, implying that a negotiator with a high EI may be too empathetic and consequently be exploited. Although, the study by Der foo et al. (2004) was conducted among students, the application of EI in the two instances was contingent on the nature of the task or the project phase, bringing to light the third concern: the nature of the project tasks and context in studies of EI in the construction industry is often disregarded. For instance, while some authors state that anger can obstruct objectivity, leading to activities of retaliation rather than activities that foster agreement in a negotiation process (Adler et al. 1998), others argue that it may be enacted in certain contextual conditions (such as the construction industry) to achieve positive outcomes (Lindebaum and Fielden 2010). Furthermore, it was discovered that construction project participants based on site scored low on self-awareness and interpersonal relationship aspects of emotional 
intelligence in comparison to project participants working more within an office (who were more external to site activities), who had higher scores on empathy and social responsibility (Songer et al. 2004). Arguably, this implies that the nature of activities on site may require one to possess or exhibit less of certain EI skills.

Research on the use of EI in construction needs to consider certain aspects of the industry in terms of the way gender relates to the experiencing, expressing and enacting of certain emotions in order to create effective relationships (Fischer 2000). Such investigations will benefit from emerging concepts in the social sciences and the area of organisational studies. Organisational identity and culture are areas on which research activities have focused. Organisations are basically created, organised and populated by people and, since they operate to achieve the goals of the founders or originators, it is assumed that organisations take on identities that are in some way reflective of the identities of those people, therefore organisational identity is regarded as a representation that extends from the purview of individual (or group identity) and is currently shown to associate with organisational performance (Gioia and Patvardhan 2012). The concept of individual identity builds on the notion that identity is a relational construct, shaped through interaction with others and the organisation's environment (Hatch and Schultz 2002).

Due to the increasing level of complexity and dynamism at the macro level of organisations in general, studies on identity are gaining relevance. This is because having an internal cognitive structure of what an organisation represents and stands for becomes necessary when redesigning or recreating conventional structures to become more flexible and competency - based heterogeneous bodies (Phua 2013). 
Consequently, in addition to organisational identity, the individual identity of employees has become a concern at the micro level (Albert et al. 2000).

Neglecting to consider the identities of construction professionals in relation to their work environment is a possible cause hindering the development of EI research in the construction industry. Faulkner (2007) argued that male professionals prefer to adopt a more technical-oriented identity. In addition, the perception that the tendency to assess the performance of construction workers against behaviours such as aggressiveness and adversarial relationships (Loosemore and Galea 2008), seems to contradict the view that EI is a powerful management tool for a construction professional to use when seeking success in his or her job (Saini and Soni 2016). The construction industry is generally regarded as one that relies on transactional relationships in order to cope with the relatively short-term pressures of projects, and therefore EI maybe be construed as a concept that threatens the identity of construction professionals (Lindebaum and Cassell 2012) due to its perception as a long-term strategy. In reality, these professionals deal with the challenges of their formal roles and project practice by developing identities that adapt to the varying conditions in which they find themselves (Gluch 2009). However, these realities are not properly considered or reflected upon in a majority of the EI studies reviewed.

The role of the nature of 'task' has also been raised in EI studies in construction. Based on an empirical study, Lindebaum and Jordan (2012) argue that activities requiring more emotional processing (such as communication) are more likely to be associated with EI than activities requiring rational abilities such as scheduling tasks. Studies have suggested that due to the nature of 'task', construction professionals need to adopt a 
leadership style based on an assessment of the situation (Zulch 2014). Some scholars also suggest that a transactional style of leadership should be used in simple projects, while EI - related skills should be applied in complex projects (Müller and Turner 2010). A further enquiry investigating the impact of the type of project delivery method on EI or the 'response' of EI on a delivery method is relevant in order to build on the above theoretical implication.

An additional line of enquiry, based on the findings from the review, is to undertake studies that consider the notion of 'cultural orientation' in relation to the practice of EI by construction professionals and project managers. The reason being that an individual's perception, belief or behaviour in the area of social relations with others and with the environment is influenced by culture. Cultural dimensions, such as individualism and collectivism are traditionally treated as national culture concepts (as based on Hofstede's work), where a country or a group of countries is the unit of analysis. However, an emerging approach in construction management studies argues for research to be conducted using individuals as the unit of analysis, in addition to the former approach. This is because it is assumed that such measurements will be more substantial when used to predict behaviours of individual workers and also organisational behaviours such as predisposition for teamwork or cooperation (Phua 2013). Hofstede's cultural model has been critiqued for focusing only at the general level of evaluation and thus not being adequate for investigating individual orientation (Taras et al. 2009). An example of an objective for investigating EI in the construction industry would be to explore the nature of individualist and collectivist preferences relating to the use of EI by construction professionals. A study with similar focus was carried out by Baarts (2009) in relation to the practice of onsite construction safety. 


\section{Methodological concerns}

Individual-level constructs such as 'Identity' and 'Culture' (in terms of individual behaviours) are usually psychologically oriented, and thus often adopt the traditionally deductive positivist approach (Fineman 2004; Phua and Rowlinson 2004). This standpoint is reflected in the majority of the reviewed studies and in mainstream organisational/ management studies where the focus is to explore, measure quantity and establish correlations between variables of interest. Even though these studies have significantly advanced our knowledge and understanding of how and why different dimensions contained in certain concepts impact on outcomes in different ways, the need to apply an alternate methodological approach has been recognised in the construction management literature (Phua, 2013; Toor and Ofori, 2008). Socially constructed phenomenon such as EI, conceptualized at the level of the individual, can have an effect on top-level decisions and overall performance (e.g Waldman and Yammarino, 1999) and therefore should be investigated qualitatively as well as quantitatively. Fineman (2004) points out that such qualitative findings are 'thick' in texture and interpretive - 'rich' in meanings, multidimensional and open about ambiguities and contradictions. It is also argued that qualitative approaches capture complexity rather than the uniformity which is often found in quantitative methods (Wels 2002). For instance, in investigating the nature of construed identity as a set of narratives about self, using an interpretative approach is argued to be appropriate (Brown and Phua 2011). In-depth case study and ethnography, both offering insight and understanding on issues pertaining to individuals' self-conception with regard to their role and environment are suggested to be very useful approaches (Phua 2013; Wels 2002). Similarly, use of autoethnography and reflection-in-action was suggested and used as a tool to assist in understanding emotional intelligence (Livesey 2013). In 
addition, the grounded theory approach, which aims to generate theory that is submerged in data, is beneficial for research associated with human behaviour in organisations (Ofori 2008; Glaser 1992). This approach has been used in construction management research to provide accounts of incidents such as women's career development (Dainty et al. 2000). The use of qualitative methodologies in exploring social constructed phenomenon is important in aiding the deciphering and discovery of issues in a manner that is often not directly handled by quantitative methodologies.

\section{Conclusions}

The relevance of this study is as follows:

(1) It confirms that human and psychological factors receive minimal interests in construction literature, as asserted by Phua (2013).

(2) It evidences the limited amount of studies of EI in the construction industry (Mischung et al. 2015; Saini and Soni 2016).

(3) It evidences limited studies of leadership, in general, in the construction industry (Toor and Ofori 2008).

(4) It provides suggestions on how these issues (and how harnessing the benefits of EI) can be addressed by incorporating 'Identity and Culture' constructs during investigations using qualitative approaches.

This research evidences a deficit of alternative methodological approaches in EI studies in construction (and in construction literature in general as claimed by some scholars Phua 2013; Ofori and Toor 2009). Previous studies were mainly quantitative, and aimed at establishing the correlation of EI and specific personality or behavioural variables. 
There is no doubt that the findings from these quantitative studies indicate the relevance of EI in construction. Nonetheless, despite the findings from previous studies, which highlights the importance of EI in construction, it is puzzling why the issue of the unwillingness of the construction industry to fully embrace this concept still persists.

The current study reviewed the literature in order to delineate the characteristics of past research conducted on EI in the construction industry, discuss potential lines of enquiry that will aid future research on EI in construction and finally proposes how the practical benefits of EI can be harnessed by deliberating methodological approaches of exploring EI in the context of construction.

Due to the plethora of research on emotional intelligence in general organisational and management literature, there is a tendency to believe that considerable studies have been conducted in the construction industry with regards to EI. This deficiency affects the development of EI in areas such as teaching one how to apply the skill and recognising when to use it.

Characteristics of reviewed studies include a predominance of quantitative methodology. It is also observed that there is scarce consideration for any cultural dimension (both macro and micro level) and a marginal concern for the nature of the task/activities, which are possible areas that research in EI can follow. A consideration of these constructs is based on the multi-organisation and multi-stakeholder nature of construction projects which give rise to numerous objectives and conflicting interest often leading to division in cultural and social aspects. 
An inference from the assessed studies and the assertions from scholars on the limited knowledge of EI in construction points to the fact that having an awareness of emotional intelligence and/or being emotionally intelligent does not necessary automatically guarantee improved performance. Recognising when to utilize EI and knowing how to implement the skill will offer more benefit to construction professionals. While the excess of quantitative approaches offers an achievement in terms of rational/objective views of the EI concept, consideration of individual identities, cultural aspects and the type or nature of project activity during investigation will provide additional valuable insights on how EI is understood, applied, trained and enhanced in the construction industry.

In conclusion, this paper proposes the use of qualitative methodologies in order to reveal the nature and behaviour of construction project managers and professionals within their work environment in relation to EI. It proposes that EI should be filtered through alternative methods of investigation such as in-depth interviews, action research and discursive methods, in other to explore ways of harnessing the concept in construction. Finally, the consideration of concepts such as 'Identity' and 'Culture' and the nature of project activity during EI research offers the possibility of discovering more insights on how EI can be trained and used in construction organisations.

\section{Disclosure Statement}

No potential conflict of interest was reported by the authors. 


\section{References}

Adler RS, Rosen B, Silverstein EM. 1998. Emotions in negotiation: How to manage fear and anger. Negotiation Journal. 14(2):161-79.

Albert S, Ashforth BE, Dutton JE. 2000. Organizational identity and identification: Charting new waters and building new bridges. Academy of Management Review. 25(1):13-7

Antonakis J, Ashkanasy NM, Dasborough MT. 2009. Does leadership need emotional intelligence? The Leadership Quarterly. 20(2):247-61

Antonakis J. 2003. Why "emotional intelligence" does not predict leadership effectiveness: A comment on prati, douglas, ferris, ammeter, and buckley (2003). The International Journal of Organizational Analysis. 11(4):355-61

Antonakis J. 2004. On why "emotional intelligence" will not predict leadership effectiveness beyond IQ or the "big five": An extension and rejoinder. Int J Organ Anal. 12(2):171-82.

Ashforth BE, Humphrey RH. 1995. Emotion in the workplace: A reappraisal. Human Relations. 48(2):97-125

Ashkanasy NM, Daus CS. 2005. Rumors of the death of emotional intelligence in organizational behavior are vastly exaggerated. J Organ Behav. 26(4):441-52.

Barbuto JE, Burbach ME. 2006. The emotional intelligence of transformational leaders: A field study of elected officials. J Soc Psychol. 146(1):51-64.

Bar-On R. 2006. The bar-on model of emotional-social intelligence (ESI) 1. Psicothema. 18(Suplemento):13-25.

Baumeister RF, Vohs KD, Nathan DeWall C, Zhang L. 2007. How emotion shapes behavior: Feedback, anticipation, and reflection, rather than direct causation. Personality and Social Psychology Review. 11(2):167-203.

Brotheridge CM, Grandey AA. 2002. Emotional labor and burnout: Comparing two perspectives of "people work". J Vocat Behav. 60(1):17-39.

Brown AD, Phua FT. 2011. Subjectively construed identities and discourse: Towards a research agenda for construction management. Constr Manage Econ. 29(1):8395

Butler CJ, Chinowsky PS. 2006. Emotional intelligence and leadership behavior in construction executives. J Manage Eng. 22(3):119-25 
Cacamis ME, El Asmar M. 2013. Improving project performance through partnering and emotional intelligence. Pract Periodical Struct Des Constr. 19(1):50-6

Cao J, Fu Y, Fu Z. 2011. The relationship between emotional intelligence and transformational leadership behavior of project managers in construction project. International Journal of Digital Content Technology and its Applications. 5(12).

Cao J, Fu Y. 2011. A survey on the role of emotional intelligence in construction project. Advance in Information Sciences and Service Sciences (AISS). 3(9):107-13.

Caruso DR, Salovey P. 2004. The emotionally intelligent manager: How to develop and use the four key emotional skills of leadership. John Wiley \& Sons.

Chinowsky P, Brown H. 2004. The development of successful intelligence in construction education. Proceedings of the 20th annual conference of the association of researchers in construction management. $525 \mathrm{p}$.

Cooper R. 1998. Sentimental value. People Management. 4(7):48-51.

Côté S, Miners CT. 2006. Emotional intelligence, cognitive intelligence, and job performance. Adm Sci Q. 51(1):1-28

Dainty AR, Bagilhole BM, Neale RH. 2000. A grounded theory of women's career under-achievement in large UK construction companies. Construction Management \& Economics. 18(2):239-50

Dainty AR, Bryman A, Price AD. 2002. Empowerment within the UK construction sector. Leadership \& Organization Development Journal. 23(6):333-42.

Der Foo M, Anger Elfenbein H, Hoon Tan H, Chuan Aik V. 2004. Emotional intelligence and negotiation: The tension between creating and claiming value. Int J Conflict Manage. 15(4):411-29.

Domagalski TA. 1999. Emotion in organizations: Main currents. Human Relations. 52(6):833-52.

Druskat V, Druskat P. 2006. Applying emotional intelligence in project working. The Management of Complex Projects: A Relationship Approach. :78-96.

Fernández-Berrocal P, Extremera N. 2006. Emotional intelligence: A theoretical and empirical review of its first 15 years of history. Psicothema. 18(Suplemento):712.

Fineman S. 2000. Emotion in organizations. Sage.

Fineman S. 1999. Emotion and organizing. Studying Organization: Theory and Method. $: 289-310$. 
Fischer A. 2000. Gender and emotion: Social psychological perspectives. Cambridge University Press

Geher G. 2004. Measuring emotional intelligence: Common ground and controversy. Nova Science Pub Incorporated.

George JM. 2000. Emotions and leadership: The role of emotional intelligence. Human Relations. 53(8):1027-55

Gioia D, Patvardhan S. 2012. Identity as process and flow. Constructing Identity in and Around Organizations. 3:50-62

Giritli H, Oraz GT. 2004. Leadership styles: Some evidence from the turkish construction industry. Constr Manage Econ. 22(3):253-62.

Goleman D. 1996. Emotional intelligence. why it can matter more than IQ. Learning. 24(6):49-50.

Goleman D. 2004. Emotional intelligence and working with emotional intelligence. London: Bloomsburg Publishing Plc

Glaser BG. 1992. Emergence vs forcing: Basics of grounded theory analysis. Sociology Press.

Gluch P. 2009. Unfolding roles and identities of professionals in construction projects: Exploring the informality of practices. Constr Manage Econ. 27(10):959-68.

Grant MJ, Booth A. 2009. A typology of reviews: An analysis of 14 review types and associated methodologies. Health Information \& Libraries Journal. 26(2):91-108

Hancock P, Tyler M. 2009. 'Emotion at Work', in T. Redman and A. Wilkinson (eds) Contemporary Human Resource Management, London: Prentice Hall

Härtel E, Ashkanasy NM, Ashkanasy N, Haertel C, Zerbe W. 2002. Managing emotion in workplace relationships. Managing Emotions in the Workplace. :135

Hatch MJ, Schultz M. 2002. The dynamics of organizational identity. Human Relations. 55(8):989-1018.

Hochschild AR. 2003. The managed heart: Commercialization of human feeling, with a new afterword. Berkeley, CA: University of California Press

Hodgson D, Cicmil S. 2006. Making projects critical. Basingstoke: Palgrave McMillan Publishing

Holweg M. 2007. The genealogy of lean production. J Oper Manage. 25(2):420-37.

Hofstede G. 1983. National cultures in four dimensions: A research-based theory of cultural differences among nations. International Studies of Management \& Organization. 13(1/2):46-74. 
Kupers W, Weibler Jr. 2008. Emotions in organisation: An integral perspective. International Journal of Work Organisation and Emotion. 2(3):256-87.

Landy FJ. 2005. Some historical and scientific issues related to research on emotional intelligence. Journal of Organizational Behavior. 26(4):411-24

Langhorn S. 2004. How emotional intelligence can improve management performance. International Journal of Contemporary Hospitality Management, 16(4):220-30

Larsson J, Eriksson PE, Olofsson T, Simonsson P. 2015. Leadership in civil engineering: Effects of project managers' leadership styles on project performance. J Manage Eng. 31(6):04015011.

Law KS, Wong C, Song LJ. 2004. The construct and criterion validity of emotional intelligence and its potential utility for management studies. J Appl Psychol. 89(3):483

Law KS, Wong C, Huang G, Li X. 2008. The effects of emotional intelligence on job performance and life satisfaction for the research and development scientists in china. Asia Pacific Journal of Management. 25(1):51-69.

Lawani A. 2016. An overview of emotional intelligence research in construction project management: Methodological concerns. Proceedings of the 32nd annual ARCOM conference, 5-7 september 2016, manchester, UK, association of researchers in construction management. $639 \mathrm{p}$

Lazarus RS. 1991. Emotion and adaptation. Oxford University Press on Demand.

Lerner JS, Small DA, Loewenstein G. 2004. Heart strings and purse strings carryover effects of emotions on economic decisions. Psychological Science. 15(5):33741.

Lindebaum D, Cartwright S. 2010. A critical examination of the relationship between emotional intelligence and transformational leadership. Journal of Management Studies. 47(7):1317-42

Lindebaum D, Fielden S. 2011. 'It's good to be angry': Enacting anger in construction project management to achieve perceived leader effectiveness. Human Relations. 64(3):437-58.

Lindebaum D, Jordan PJ. 2012. Relevant but exaggerated: The effects of emotional intelligence on project manager performance in construction. Constr Manage Econ. 30(7):575-83. 
Lindebaum D, Cassell C. 2012. A contradiction in terms? Making sense of emotional intelligence in a construction management environment. Br J Manage. 23(1):6579.

Livesey P. 2013. What does it take to manage larger construction projects: The role of emotional intelligence, reflection-in-action and autoethnography. Australian institute of project management, national conferenceAIPM.

Locke EA. 2005. Why emotional intelligence is an invalid concept. J Organ Behav. 26(4):425-31.

Loosemore M, Galea N. 2008. Genderlect and conflict in the australian construction industry. Constr Manage Econ. 26(2):125-35.

Loosemore M, Dainty A, Lingard H. 2003. Human resource management in construction projects: Strategic and operational approaches. Taylor \& Francis.

Lopes PN, Salovey P, Côté S, Beers M, Petty RE. 2005. Emotion regulation abilities and the quality of social interaction. Emotion. 5(1):113.

Love PED, Holt GD, Shen LY, Li H, Irani Z. 2002. Using systems dynamics to better understand change and rework in construction project management systems. Int J Project Manage. 20(6):425-36

Love P, Edwards D, Wood E. 2011. Loosening the Gordian knot: The role of emotional intelligence in construction. Engineering, Construction and Architectural Management. 18(1):50-65

Lyusin D. 2006. Emotional intelligence as a mixed construct: Its relation to personality and gender. Journal of Russian \& East European Psychology. 44(6):54-68

Mandell B, Pherwani S. 2003. Relationship between emotional intelligence and transformational leadership style: A gender comparison. Journal of Business and Psychology. 17(3):387-404

Mayer JD, Roberts RD, Barsade SG. 2008. Human abilities: Emotional intelligence. Annu Rev Psychol. 59:507-36

Mayer J. 1997. What is emotional intelligence? From salovey, P and sluyter, D.(eds.) emotional development and emotional intelligence: Educational implications.

McEnrue MP, Groves K. 2006. Choosing among tests of emotional intelligence: What is the evidence? Human Resource Development Quarterly. 17(1):9-42

Mischung JJ, Smithwick JB, Sullivan KT, Perrenoud AJ. A review of emotional intelligence and considerations for EI's use within construction management 
programs. Proceedings of the 51st Annual International Conference Proceedings.

Müller R, Turner R. 2010. Leadership competency profiles of successful project managers. Int J Project Manage. 28(5):437-48.

Mo Y, Dainty A, Price A. 2006. The relevance of EQ to construction project management education and practice: An investigative framework. Management. $823: 831$

Mo Y, Dainty A, Price A. 2007. An assessment of the emotional intelligence of construction students: An empirical investigation. 23rd annual ARCOM conference. $3 \mathrm{p}$.

Morgan G. 1997. Images of organization. California: Sage Publications

O'Boyle EH, Humphrey RH, Pollack JM, Hawver TH, Story PA. 2011. The relation between emotional intelligence and job performance: A meta-analysis. J Organ Behav. 32(5):788-818.

Ofori G. 2008. Grounded theory as an appropriate methodology for leadership research in construction

Overbeck JR, Neale MA, Govan CL. 2010. I feel, therefore you act: Intrapersonal and interpersonal effects of emotion on negotiation as a function of social power. Organ Behav Hum Decis Process. 112(2):126-39.

Ozorhon B, Abbott C, Aouad G. 2013. Integration and leadership as enablers of innovation in construction: Case study. J Manage Eng. 30(2):256-63

Phua FT. 2013. Construction management research at the individual level of analysis: Current status, gaps and future directions. Constr Manage Econ. 31(2):167-79

Phua FT, Rowlinson S. 2004. Operationalizing culture in construction management research: A social identity perspective in the hong kong context. Constr Manage Econ. 22(9):913-25.

Pryke S, Smyth H. 2012. The management of complex projects: A relationship approach. John Wiley \& Sons.

Pryke S, Lunic D, Badi S. 2015. The effect of leader emotional intelligence on leaderfollower chemistry: A study of construction project managers. Constr Manage Econ. 33(8):603-24.

Ragins BR, Winkel DE. 2011. Gender, emotion and power in work relationships. Human Resource Management Review. 21(4):377-93 
Rosete D, Ciarrochi J. 2005. Emotional intelligence and its relationship to workplace performance outcomes of leadership effectiveness. Leadership \& Organization Development Journal. 26(5):388-99

Saini A, Soni N. 2016. Role of Emotional Intelligence in Construction Industry: A Review. Int J Civil Eng and Tech. 7(4): 339-44.

Salovey P, Mayer JD. 1990. Emotional intelligence. Imagination, Cognition and Personality. 9(3):185-211

Satchwell L, Smallwood J. The role of emotional intelligence in managing construction projects. International Organizing Committee. :557

Sears SK, Sears GA, Clough RH. 2010. Construction project management: A practical guide to field construction management. John Wiley \& Sons.

Shields SA. 2005. The politics of emotion in everyday life:" appropriate" emotion and claims on identity. Review of General Psychology. 9(1):3

Simpson R. 2006. Book review: Men and the language of emotions. International Journal of Work Organisation and Emotion. 1(4):402-3

Sinaceur M, Tiedens LZ. 2006. Get mad and get more than even: When and why anger expression is effective in negotiations. J Exp Soc Psychol. 42(3):314-22.

Songer AD, Walker B, Beliveau Y. 2004. Central contractor emotional intelligence in the construction industry. Proceedings of the 20th annual conference of the association of researchers in construction management. $488 \mathrm{p}$

Spielberger C. 2004. Encyclopedia of applied psychology. Academic Press. San Diego, CA:

Sprague LG. 2007. Evolution of the field of operations management. J Oper Manage. 25(2):219-38.

Sunindijo RY, Hadikusumo BH. 2013. Emotional intelligence for managing conflicts in the sociocultural norms of the thai construction industry. J Manage Eng. 30(6):04014025.

Sunindijo RY, Zou PX. 2013. The roles of emotional intelligence, interpersonal skill, and transformational leadership on improving construction safety performance. Construction Economics and Building. 13(3):97-113.

Sunindijo R. 2012. Integrating emotional intelligence, political skill, and transformational leadership in construction. Civil Engineering Dimension. 14(3):182-9. 
Sunindijo RY, Hadikusumo BH, Ogunlana S. 2007. Emotional intelligence and leadership styles in construction project management. J Manage Eng. 23(4):16670.

Sy T, Tram S, O’hara LA. 2006. Relation of employee and manager emotional intelligence to job satisfaction and performance. J Vocat Behav. 68(3):461-73

Taras V, Rowney J, Steel P. 2009. Half a century of measuring culture: Review of approaches, challenges, and limitations based on the analysis of 121 instruments for quantifying culture. Journal of International Management. 15(4):357-73.

Thurnell D. 2004. Emotional intelligence and the value management facilitator. Proceedings of the 20th annual conference of the association of researchers in construction management $915 \mathrm{p}$

Tixier AJ, Hallowell MR, Albert A, Van Boven L, Kleiner BM. 2014. Psychological antecedents of risk-taking behavior in construction. J Constr Eng Manage. 140(11):04014052.

Toor S, Ofori G. 2008. Taking leadership research into future: A review of empirical studies and new directions for research. Engineering, Construction and Architectural Management. 15(4):352-71

Tranfield D, Denyer D, Smart P. 2003. Towards a methodology for developing evidence-informed management knowledge by means of systematic review. Br J Manage. 14(3):207-22.

Van Rooy DL, Viswesvaran C. 2004. Emotional intelligence: A meta-analytic investigation of predictive validity and nomological net. J Vocat Behav. 65(1):71-95.

Von Glinow MA, Shapiro DL, Brett JM. 2004. Can we talk, and should we? Managing emotional conflict in multicultural teams. Academy of Management Review. 29(4):578-92.

Waldman DA, Yammarino FJ. 1999. CEO charismatic leadership: Levels-ofmanagement and levels-of-analysis effects. Academy of Management Review. 24(2):266-85

Walter F, Cole MS, Humphrey RH. 2011. Emotional intelligence: Sine qua non of leadership or folderol? The Academy of Management Perspectives. 25(1):45-59.

Wels H. 2002. Culture, organization and management in east asia: Doing business in china. Nova Publishers 
Zeelenberg M, Nelissen RM, Breugelmans SM, Pieters R. 2008. On emotion specificity in decision making: Why feeling is for doing. Judgment and Decision Making. $3(1): 18$

Zhang L, Fan W. 2013. Improving performance of construction projects: A project manager's emotional intelligence approach. Engineering, Construction and Architectural Management. 20(2):195-207

Zulch B. 2014. Leadership communication in project management. Procedia-Social and Behavioral Sciences. 119:172-81 
Table 1. Article selection process

\begin{tabular}{|c|c|c|c|c|c|c|}
\hline & $\begin{array}{l}\text { ICONDA CIB } \\
\text { library }\end{array}$ & $\begin{array}{l}\text { Leadership } \\
\text { Quarterly }\end{array}$ & $\begin{array}{l}\text { Human } \\
\text { Relations }\end{array}$ & $\begin{array}{l}\text { ASCE } \\
\text { library }\end{array}$ & ARCOM & Total \\
\hline Keyword - Emotional & & & & & & \\
\hline Intelligence & 5 & & & 227 & 11 & 243 \\
\hline $\begin{array}{l}\text { Keyword - Leadership } \\
\text { styles }\end{array}$ & 10 & 30 & & & 12 & 52 \\
\hline $\begin{array}{l}\text { Key phrase - Emotion } \\
\text { intelligence in } \\
\text { Construction Project }\end{array}$ & & & & & & \\
\hline Management & & 45 & 44 & & & 89 \\
\hline $\begin{array}{l}\text { Apply filters - } \\
\text { Construction } \\
\text { Management and/or }\end{array}$ & & & & & & \\
\hline Construction industry & & & & -184 & & -184 \\
\hline Total & 15 & 75 & 44 & 43 & 23 & 200 \\
\hline $\begin{array}{l}\text { Exclusion through } \\
\text { abstract review (non- } \\
\text { construction context) }\end{array}$ & -13 & -75 & 43 & -37 & -12 & -180 \\
\hline $\begin{array}{l}\text { Retrieved for full } \\
\text { review }\end{array}$ & 2 & 0 & 1 & 6 & 11 & 20 \\
\hline
\end{tabular}

Source: Lawani 2016 
Table 2. Characteristics of reviewed articles

\begin{tabular}{|c|c|c|c|c|c|c|}
\hline & Author(s) & Research Theme & Country & Research Method & Publication source & $\begin{array}{c}\text { Project delivery } \\
\text { method/Project } \\
\text { Task or Phase }\end{array}$ \\
\hline 1 & Saini and Soni 2016 & Assessing the role of EI in construction industry & & Review paper & $\begin{array}{l}\text { Intl' Journal of Civil } \\
\text { Engineering and } \\
\text { Technology }\end{array}$ & \\
\hline 2 & $\begin{array}{l}\text { Satchwell and } \\
\text { Smallwood } 2016\end{array}$ & The status and role of EI in the construction industry & South Africa & Qualitative approach & $\begin{array}{l}\text { Creative Construction } \\
\text { Conference }\end{array}$ & \\
\hline 3 & Pryke et.al 2015 & $\begin{array}{l}\text { Investigates the effect of a Project Manager's EI } \\
\text { competencies on the quality of interpersonal interaction } \\
\text { with followers (members of the project team). }\end{array}$ & Republic of Serbia & $\begin{array}{l}\text { Quantitative approach: } \\
\text { Analytical Surveys and } \\
\text { observations. }\end{array}$ & $\begin{array}{l}\text { Construction Management } \\
\& \text { Economics }\end{array}$ & $\begin{array}{l}\text { Project } \\
\text { Alliancing }\end{array}$ \\
\hline 4 & Mischung et al 2015 & $\begin{array}{l}\text { An experimental study that shows the impact of } \\
\text { emotional intelligence training on team performance } \\
\text { between undergraduate students of construction } \\
\text { management course. }\end{array}$ & US & $\begin{array}{l}\text { Quantitative survey: } \\
\text { measurement of } \\
\text { variance }\end{array}$ & $\begin{array}{l}\text { Conference proceedings : } \\
\text { 122nd ASEE Annual } \\
\text { Conference \& Exposition }\end{array}$ & \\
\hline 5 & Tixier et al. 2014 & $\begin{array}{l}\text { An experiment conducted to measure the difference in } \\
\text { construction safety risk perception between project } \\
\text { participants in different emotional states. }\end{array}$ & US & $\begin{array}{l}\text { Quantitative approach : } \\
\text { Principal component } \\
\text { analysis and Non } \\
\text { parametric test }\end{array}$ & $\begin{array}{l}\text { Journal of Construction } \\
\text { Engineering and } \\
\text { Management }\end{array}$ & Risk Taking \\
\hline 6 & $\begin{array}{l}\text { Cacamis and El } \\
\text { Asmar } 2013\end{array}$ & $\begin{array}{l}\text { The study proposes that developing the EI of project } \\
\text { participants can improve partnering relationships and } \\
\text { consequently increase project performance. }\end{array}$ & US & Research paper & $\begin{array}{l}\text { Practice Periodical on } \\
\text { Structural Design and } \\
\text { Construction }\end{array}$ & \\
\hline 7 & $\begin{array}{l}\text { Sunindijo and } \\
\text { Hadikusumo } 2013\end{array}$ & $\begin{array}{l}\text { Investigates the relationship between emotional } \\
\text { intelligence and conflict resolution styles. }\end{array}$ & Thailand & $\begin{array}{l}\text { Quantitative approach : } \\
\text { Questionnaire surveys }\end{array}$ & $\begin{array}{l}\text { Journal of Management in } \\
\text { Engineering }\end{array}$ & $\begin{array}{l}\text { Conflict } \\
\text { resolutions }\end{array}$ \\
\hline 8 & $\begin{array}{l}\text { Sunindijo and Zou, } P \\
2013\end{array}$ & $\begin{array}{l}\text { Investigates the influence of project management } \\
\text { personnel's EI, interpersonal and transformational } \\
\text { leadership skill on the implementation of safety } \\
\text { management tasks in construction projects. }\end{array}$ & Australia & $\begin{array}{l}\text { Quantitative : } \\
\text { Regression analysis }\end{array}$ & $\begin{array}{l}\text { Australasian Journal of } \\
\text { Construction Economics } \\
\text { and Building }\end{array}$ & $\begin{array}{l}\text { Safety } \\
\text { Management } \\
\text { tasks }\end{array}$ \\
\hline 9 & Zhang and Fan 2013 & $\begin{array}{l}\text { Examines the benefits of a Project manger's EI to } \\
\text { project performance. }\end{array}$ & China & $\begin{array}{l}\text { Quantitative : } \\
\text { Correlational analysis }\end{array}$ & $\begin{array}{l}\text { Engineering, Construction } \\
\text { and Architectural } \\
\text { Management }\end{array}$ & $\begin{array}{l}\text { International } \\
\text { projects: } \\
\text { contracting }\end{array}$ \\
\hline
\end{tabular}




\begin{tabular}{|c|c|c|c|c|c|c|}
\hline & Author(s) & Research Theme & Country & Research Method & Publication source & $\begin{array}{c}\text { Project delivery } \\
\text { method/Project } \\
\text { Task or Phase }\end{array}$ \\
\hline 10 & Livesey 2013 & $\begin{array}{l}\text { Paper discusses the need for emotional intelligence in } \\
\text { large construction projects and how the use of } \\
\text { autoethnography and reflection-in-action can assist in } \\
\text { developing EI. }\end{array}$ & & Review paper & $\begin{array}{l}\text { Australian Institute of } \\
\text { Project Management, } \\
\text { National Conference }\end{array}$ & \\
\hline 11 & $\begin{array}{l}\text { Lindebaum and } \\
\text { Cassell } 2012\end{array}$ & $\begin{array}{l}\text { Assessing the possible application of EI in the } \\
\text { construction environment. }\end{array}$ & UK & $\begin{array}{l}\text { Interpretivist approach : } \\
\text { narrative analysis }\end{array}$ & $\begin{array}{l}\text { British Journal of } \\
\text { Management }\end{array}$ & \\
\hline 12 & $\begin{array}{l}\text { Lindebaum and } \\
\text { Jordan } 2012\end{array}$ & $\begin{array}{l}\text { Investigates dimensions of performance in relation to a } \\
\text { project manager's EI. }\end{array}$ & UK & $\begin{array}{l}\text { Quantitative : } \\
\text { Correlational and } \\
\text { Regression analysis }\end{array}$ & $\begin{array}{l}\text { Construction Management } \\
\& \text { Economics }\end{array}$ & $\begin{array}{l}\text { Cognitive and } \\
\text { Relational tasks }\end{array}$ \\
\hline 13 & Sunindijo 2012 & $\begin{array}{l}\text { Investigates the relationship between emotional } \\
\text { intelligence, political skill and transformational } \\
\text { leadership in construction project environment. }\end{array}$ & Australia & $\begin{array}{l}\text { Quantitative: Structural } \\
\text { equation modelling }\end{array}$ & $\begin{array}{l}\text { Civil Engineering } \\
\text { Dimension }\end{array}$ & \\
\hline 14 & Love et al 2011 & $\begin{array}{l}\text { Suggests directions on how EI can be used to improve } \\
\text { the performance of construction projects. - Research } \\
\text { paper }\end{array}$ & & Analytic review & $\begin{array}{l}\text { Engineering, Construction } \\
\text { and Architectural } \\
\text { Management }\end{array}$ & \\
\hline 15 & Cao et al 2011 & $\begin{array}{l}\text { Investigates the relationship between the components of } \\
\text { EI and transformational leadership behaviour of a } \\
\text { construction project manager. }\end{array}$ & China & $\begin{array}{l}\text { Quantitative : } \\
\text { Regression analysis }\end{array}$ & $\begin{array}{l}\text { International Journal of } \\
\text { Digital Content } \\
\text { Technology and its } \\
\text { Applications }\end{array}$ & \\
\hline 16 & Cao and Fu 2011 & $\begin{array}{l}\text { A report on the benefits of EI in construction industry } \\
\text { and how it can be used to improve performance of } \\
\text { construction projects. }\end{array}$ & & Review paper & $\begin{array}{l}\text { Advances in information } \\
\text { Sciences and Service } \\
\text { Sciences(AISS) }\end{array}$ & \\
\hline 17 & $\begin{array}{l}\text { Lindebaum and } \\
\text { Fielden } 2010\end{array}$ & $\begin{array}{l}\text { Investigate the positive effects of enacting negative } \\
\text { emotions (anger) in the construction industry. }\end{array}$ & UK & $\begin{array}{l}\text { Qualitative } \\
\text { phenomenological } \\
\text { research }\end{array}$ & Human Relations & \\
\hline
\end{tabular}




\begin{tabular}{|c|c|c|c|c|c|c|}
\hline & Author(s) & Research Theme & Country & Research Method & Publication source & $\begin{array}{c}\text { Project delivery } \\
\text { method/Project } \\
\text { Task or Phase }\end{array}$ \\
\hline 18 & Sunindijo et al. 2007 & $\begin{array}{l}\text { Investigates the Benefits of EI to Construction project } \\
\text { Management in relation to leadership styles. }\end{array}$ & Thailand & $\begin{array}{l}\text { Quantitative: } \\
\text { Correlational analysis }\end{array}$ & $\begin{array}{l}\text { Journal of Management in } \\
\text { Engineering }\end{array}$ & \\
\hline 19 & Mo et al 2007 & $\begin{array}{l}\text { Examines the level of EI in engineering undergraduates and } \\
\text { the degree to which construction educational programes } \\
\text { develop students' EI. }\end{array}$ & UK & $\begin{array}{l}\text { Quantitative: } \\
\text { Correlational analysis }\end{array}$ & $\begin{array}{l}\text { Conference Proceedings - } \\
\text { Association of Researchers } \\
\text { in Construction } \\
\text { Management. }\end{array}$ & \\
\hline 20 & Mo et al. 2006 & $\begin{array}{l}\text { Explores the EI level of construction management MSc } \\
\text { students and investigates the impact of the course content } \\
\text { on their EI development. }\end{array}$ & UK & $\begin{array}{l}\text { Quantitative: } \\
\text { Correlational analysis }\end{array}$ & $\begin{array}{l}\text { Journal for Education in the } \\
\text { Built Environment }\end{array}$ & \\
\hline 21 & $\begin{array}{l}\text { Butler and Chinowsky } \\
2006\end{array}$ & $\begin{array}{l}\text { Examines the relationship between EI and transformational } \\
\text { leadership behaviours }\end{array}$ & US & $\begin{array}{l}\text { Quantitative: } \\
\text { Discriminant and } \\
\text { Regression analysis }\end{array}$ & $\begin{array}{l}\text { Journal of Management in } \\
\text { Engineering }\end{array}$ & \\
\hline 22 & $\begin{array}{l}\text { Mo, Danity and Price } \\
2006\end{array}$ & $\begin{array}{l}\text { A review of EI literature and its importance in the } \\
\text { Construction industry. }\end{array}$ & UK & Research paper & $\begin{array}{l}\text { Conference Proceedings - } \\
\text { Association of Researchers } \\
\text { in Construction } \\
\text { Management. }\end{array}$ & \\
\hline 23 & $\begin{array}{l}\text { Songer and Walker } \\
2004\end{array}$ & Investigating EI in General Contracting Sector. & US & $\begin{array}{l}\text { Quantitative: Regression } \\
\text { Analysis }\end{array}$ & $\begin{array}{l}\text { Conference Proceedings - } \\
\text { Association of Researchers } \\
\text { in Construction } \\
\text { Management. }\end{array}$ & Contracting \\
\hline 24 & $\begin{array}{l}\text { Chinowsky, P and } \\
\text { Brown, H } 2004\end{array}$ & $\begin{array}{l}\text { Analyses the impact of current engineering courses on the } \\
\text { development of emotional intelligence in construction } \\
\text { students with the prospect of enhancing emotional } \\
\text { intelligence development. }\end{array}$ & US & $\begin{array}{l}\text { Quantitative: Goodness of } \\
\text { fit test, descriptive } \\
\text { analysis }\end{array}$ & $\begin{array}{l}\text { Conference Proceedings - } \\
\text { Association of Researchers } \\
\text { in Construction } \\
\text { Management. }\end{array}$ & \\
\hline 25 & Der Foo et al 2004 & $\begin{array}{l}\text { Investigates the relationship between the members of a } \\
\text { dyad involved in a negotiation. }\end{array}$ & China & $\begin{array}{l}\text { Quantitative : Multiple } \\
\text { Regression }\end{array}$ & $\begin{array}{l}\text { The International Journal of } \\
\text { Conflict Management. }\end{array}$ & Negotiation stage \\
\hline 26 & Thurnell 2004 & $\begin{array}{l}\text { Examines how EI, Value management facilitation and } \\
\text { group management impacts on Value management in the } \\
\text { Construction Industry. }\end{array}$ & New Zealand & Review paper & $\begin{array}{l}\text { Conference Proceedings - } \\
\text { Association of Researchers } \\
\text { in Construction } \\
\text { Management. }\end{array}$ & \\
\hline
\end{tabular}

